\title{
EFFICIENCY OF PRIMARY NET PHYTOMASS PRODUCTION OF Eucalyptus dunnii Maiden SEEDLINGS.
}

\author{
Sérgio Costa Junior ${ }^{1}$, Ana Paula Dalla Corte ${ }^{1}$, Alexandre Behling ${ }^{1}$, Jonatham William Trautenmuller ${ }^{1}$ Antonio \\ Pedro Fragoso Woycikievicz ${ }^{1 *}$ Juliane Borella $^{1}$ \\ ${ }^{1}$ Federal University of Paraná, Curitiba, Paraná, Brazil - o.sergio.costa@gmail.com; anapaulacorte@gmail.com; \\ alexandre.behling@gmail.com; jwtraute@gmail.com; antoniof.w@gmail.com*; borella.juli@gmail.com \\ Received for publication: 23/10/2018 - Accepted for publication: 17/09/2019
}

\begin{abstract}
Resumo
Eficiência da produção primária líquida de fitomassa de mudas de Eucalyptus dunnii Maiden. O objetivo do estudo foi testar a influência da densidade de plantas, do ambiente de cultivo e da estação do ano na eficiência de conversão $(\varepsilon b)$ da radiação fotossinteticamente ativa interceptada em fitomassa de mudas de Eucalyptus dunnii Maiden. Para tanto, foi conduzido um experimento em que foram avaliadas 2 densidades de mudas por bandeja (100\% e $50 \%$ de ocupação), 2 ambientes de cultivo (natural e estufa) e 2 estações (verão e outono). Foram realizadas determinações da produção primária líquida de fitomassa, índice de área foliar e radiação fotossinteticamente ativa interceptada acumulada, o que possibilitou calcular a $\varepsilon b$ dessa radiação em fitomassa. Foi evidenciada a rejeição da hipótese da nulidade, ou seja, os fatores pesquisados (densidade de plantas, ambiente de cultivo e estações do ano) influenciaram nos valores da $\varepsilon b$. A melhor $\varepsilon b$ foi de $7,59 \mathrm{~g} \mathrm{MJ}^{-1}$ obtida no experimento conduzido no verão, em ambiente estufa e na densidade de $100 \%$ de ocupação da bandeja. Não foi observada a dependência dos fatores na $\varepsilon b$, ou seja, as melhores $\varepsilon b$ foram no ambiente estufa e na densidade de $100 \%$, independente da estação do ano. Portanto, os fatores estudados influenciam a produção primária líquida de mudas de Eucalyptus dunnii Maiden, resultando em maior ou menor tempo de permanência das mudas no viveiro.
\end{abstract}

Palavras-chave: Radiação Fotossintética; Produção de Mudas; Densidade Ambiente de Cultivo; Estações do Ano.

\begin{abstract}
The aim of the study was to test the influence of plant density, cultivation environment and season on the conversion efficiency $(\varepsilon b)$ of photosynthetically active radiation intercepted in the phytomass of seedlings Eucalyptus dunnii Maiden. For this purpose, an experiment was conducted in which 2 seedling densities per tray (100\% and 50\% of occupation), 2 cultivation environments (natural and greenhouse) and 2 seasons (summer and autumn) were evaluated. Determinations of the net primary production of phytomass, index of leaf area and accumulated photosynthetically active radiation were carried out, which made it possible to calculate the $\varepsilon b$ of this radiation in phytomass. It was evidenced the rejection of the null hypothesis, that is, the researched factors (plant density, cultivation environment and seasons) influenced the values of $\varepsilon b$. The best $\varepsilon b$ was $7.59 \mathrm{~g} \mathrm{MJ}^{-1}$ obtained in the experiment conducted in the summer, in a greenhouse and at a density of $100 \%$ of the tray. The dependence of factors on $\varepsilon b$ was not observed, that is, the best $\varepsilon b$ were in the greenhouse environment and at $100 \%$ density, regardless of the season. Therefore, the factors studied influence the net primary production of Eucalyptus dunnii Maiden seedlings, resulting in longer or shorter seedlings in the nursery.

Keywords: Photosynthetic Radiation; Seedling Production; Density; Growing Environment; Seasons.
\end{abstract}

\section{INTRODUCTION}

Forest stands of Eucalyptus genus occupy an area of 5.7 million hectares of area trees planted in Brazil (IBÁ, 2017). According to Guimarães et al. (2015), one of the species of the genus Eucalyptus that has stood out economically in the coldest conditions of southern Brazil and having been the subject of research is the Eucalyptus dunnii Maiden. Currently the stands of the species have been implanted with seedlings produced in plastic greenhouses. However, greenhouse cultivation causes changes in meteorological elements such as, for example, solar radiation (CARON et al., 2012). This element directly affects the growth and development of seedlings, since it is a function of the phytomass balance accumulated by photosynthesis (CARON et al., 2012).

Thus, variables that alter photosynthetic processes are of interest to professionals linked to the areas of agrarian sciences, because the plant productivity and crop yields depend on photosynthetic rates (TAIZ and ZEIGER, 2004). In this sense, the phytomass production of a plant depends on the amount of photosynthetically 
active solar radiation absorbed by the leaves and on the efficiency with which the plant converts this radiant energy into photoassimilates, through of photosynthesis.

According to Monteith (1977), plants in a good phytosanitary condition that have adequate amounts of water and nutrients at their disposal, it will have dry phytomass production determined by photosynthetically active radiation (RFA). In this way, the accumulated intercepted PAR, which is converted into phytomass, reveals the efficiency of the use of radiation $(\varepsilon b)$ by the species (MONTEITH, 1977). Some works developed by Stape et al. (2008), Campoe et al. (2013), Caron et al. (2014) and Sanquetta et al. (2014) identified that this relationship has been demonstrated as a linear function, in which the angular coefficient of the curve between the accumulated intercepted RFA and the accumulated dry matter determines the efficiency of the use of radiation for the production of phytomass.

As the availability of solar radiation is one of the factors that directly affects plant growth and development (CARON et al., 2012), in the case of southern Brazil this availability presents values with significant differences in the seasons, what can influence directly the $\varepsilon b$ of that radiation.

Another factor that influences $\varepsilon b$ is the leaf area index, characteristic that can be manipulated through of plant density. Thus, studies such as those by Caron et al. $(2012,2014)$ were conducted on the grounds the photosynthetic efficiency is mainly a direct function of plant density, since the leaf area index is the factor that determines $\varepsilon b$ (TEIXEIRA et al., 2015).

Thus, this study had to evaluate the effects of the variables: plant density, cultivation environment and seasons in the efficient use of intercepted photosynthetically active solar radiation accumulated in Eucalyptus dunnii Maiden seedlings.

\section{MATERIAL AND METHODS}

\section{Experimental data}

For this study, an experiment was conducted with the species Eucalyptus dunnii during the period from November 2012 to July 2013 in the nursery of the Center of Excellence in Research on Carbon Fixation in Biomass (BIOFIX) of the Federal University of Paraná, in the municipality of Curitiba - PR, Brazil, under geographical coordinates $25^{\circ} 26^{\prime} 49^{\prime}$ S and $49^{\circ} 14$ ' 14 " W, at $935 \mathrm{~m}$ altitude.

1,120 seedlings of Eucalyptus dunnii were cultivated, of which 480 were evaluated. In the treatment planning, a $2 \times 2 \times 2$ factorial arrangement was used: two seasons, two environments and two cultivation densities, which were conducted in five replications in a completely randomized experimental design. Each experimental unit consisted of 32 and 24 plants, respectively for $100 \%$ and $50 \%$ of tray utilization, with only 12 central seedlings being evaluated.

The accumulation in total dry mass of Eucalyptus dunnii seedlings was evaluated in the seasons: summer and autumn; in cultivation environments: natural (external) and protected (greenhouse); and in two levels of plant densities in the trays: $100 \%$ and $50 \%$, called high and medium density, respectively. The high density was equivalent to approximately 746 plants $\mathrm{m}^{-2}$ and for the average of 373 plants $\mathrm{m}^{-2}$. The greenhouse was characterized by a Pampeana type, with $150 \mu \mathrm{m}$ thick polyethylene cover. The external was characterized by not having any type of coverage or protection.

Seedlings were produced from seeds from KLABIN® stands. For sowing, tubes were used, with a volume of $55 \mathrm{~cm}^{3}$ filled with commercial substrate (Tropstrato HT®). During the conduction of the experiment, daily watering was carried out using a micro-sprinkler system, always maintaining the substrate field capacity. In addition, four fertilizations were carried out by applying foliar fertilizer (Folly Fertil) with the following composition: $\mathrm{N} 15 \%\left(202 \mathrm{~g} \mathrm{~L}^{-1}\right), \mathrm{P}_{2} \mathrm{O}_{5} 22 \%\left(297 \mathrm{~g} \mathrm{~L}^{-1}\right)$ and $\mathrm{K}_{2} \mathrm{O} 2 \%\left(27 \mathrm{~g} \mathrm{~L}^{-1}\right)$. From the 50th day after germination, six phytomass evaluations were performed at 15-day intervals, in which two seedlings per treatment and repetition were sampled, totaling 480 seedlings studied at the end of the experiment.

\section{Efficiency of net primary production}

The dry phytomass production was studied based on the model proposed by Monteith (1977), in which this is a variable dependent on the amount of accumulated photosynthetically active intercepted radiation, multiplied by the conversion efficiency $(\varepsilon b)$ of this radiation into phytomass dry. Thus, the model was adjusted using regression analysis, which allowed the calculation of $\varepsilon b$ through the relationship between the average accumulated dry phytomass production and the accumulated photosynthetically active intercepted radiation involved in the phytomass production, according to the equation a follow:

$$
P F S=\varepsilon b * R F A i a c
$$


Where: $\quad$ PFS - dry phytomass production $\left(\mathrm{g} \mathrm{m}^{-2}\right)$;

RFAiac- accumulated photosynthetically active solar radiation intercepted $\left(\mathrm{MJ} \mathrm{m}^{-2}\right)$;

$\varepsilon b$ - efficiency of conversion of RFAiac radiation into produced dry phytomass $\left(\mathrm{g} \mathrm{MJ}^{-1}\right)$. estimate.

The fitted of the model was evaluated by the statistics: coefficient of determination and standard error of

The accumulated photosynthetically active intercepted radiation was estimated based on the model proposed by Varlet-Grancher et al. (1989), according to the following equation:

$$
\text { RFAiac }=0,95 *(\text { RFAinc }) *\left(1-e^{(-k * I A F)}\right)
$$

Where: $\quad$ RFAiac - accumulated photosynthetically active solar radiation intercepted $\left(\mathrm{MJ} \mathrm{m}^{-2}\right)$;

$\mathrm{K}$ - light extinction coefficient, being a dimensionless constant that depends on the optical properties of the leaves and on the geometry of the plant canopy (0.28);

IAF - leaf area index (dimensionless);

RFAinc - incident photosynthetically active radiation $\left(\mathrm{MJ} \mathrm{m}^{-2}\right)$.

The leaf area index was determined from the total leaf area of each plant and the tray area explored by it (seedling density), calculated using the following equation:

$$
I A F=A F / A E B
$$

Where: IAF - leaf area index (dimensionless);

$\mathrm{AF}$ - total leaf area of the plant $\left(\mathrm{m}^{2}\right)$;

AEB - tray area explored by the plant $\left(\mathrm{m}^{2}\right)$.

To determine the leaf area, it was used the integrator CI - 202 portable laser leaf area meter (CID Bioscience).

The components of the phytomass were taken to the forced circulation oven at a temperature of $65^{\circ} \mathrm{C}$ until reaching constant weight, afterwards, the material was weighed on a precision scale (FA2104N, Bioprecisa) to obtain the dry weight. The total dry phytomass of the plants was determined from the sum of the mass of the leaves, stem and roots components.

The values of global solar radiation, air temperature and relative humidity for the natural environment were obtained from the Climatological Station of INMET (National Institute of Meteorology) and SIMEPAR (Meteorological System of Paraná), located about $500 \mathrm{~m}$ from the experiment. The incident photosynthetically active radiation was estimated to be $50 \%$ of global solar radiation (CARON et al., 2012). In the greenhouse, the incident photosynthetically active radiation was estimated considering the transmissivity of the plastic cover of $56 \%$ of the solar radiation incident on the greenhouse cover, a constant that was measured at 10-minute intervals by a pyranometer (LI200X, Li Cor), installed at $50 \mathrm{~cm}$ above ground level for 2 months.

\section{Data analysis}

The null hypothesis was conceived as being that the study factors: seasons, cultivation environment and plant density do not influence $\varepsilon b$. This hypothesis was tested by covariance analysis (ANACOVA), using the Snedecor method. The analysis was applied to verify the need to use independent functions between the accumulated photosynthetically active intercepted radiation and the accumulation of total dry phytomass in the different treatments studied, thus determining whether there were differences between them. If the difference is not significant for the slope, at the level of 5\% significance, a single regression can be fitted, or vice versa.

The levels test was not performed, considering that the objective was to verify only the slope, since it is what determines the conversion efficiency value of the intercepted photosynthetically active radiation accumulated in phytomass.

Pearson's correlation coefficient was also calculated between the variables: area index (IAF), accumulated photosynthetically active solar radiation (RFAiac) and days after emergence (DAE), in order to verify the strength and direction of the correlation. 


\section{RESULTS}

The first seedling cultivation cycle comprised the summer season, when the global solar radiation flow in the natural environment averaged $17 \mathrm{MJ} \mathrm{m}^{-2}$ day $^{-1}$, with a range of 3.6 to $30,2 \mathrm{MJ} \mathrm{m}^{-2}$ day $^{-1}$, while inside the greenhouse, it was on average $9.5 \mathrm{MJ} \mathrm{m}^{-2} \mathrm{day}^{-1}$, with a range from 2 to $16.9 \mathrm{MJ}^{-2} \mathrm{~m}^{-2} \mathrm{day}^{-1}$. The second cycle occurred in autumn, in which the global solar radiation flow averaged $12.5 \mathrm{MJ} \mathrm{m}^{-2}$ day $^{-1}$, with a range from 1 to $27.6 \mathrm{MJ} \mathrm{m}^{-2} \mathrm{dia}^{-1}$, already inside the greenhouse, averaged $7 \mathrm{MJ} \mathrm{m}^{-2}$ day $^{-1}$, with a variation from 0.6 to $15.5 \mathrm{MJ} \mathrm{m}^{-}$ ${ }^{2}$ day $^{-1}$ (Figure 1).

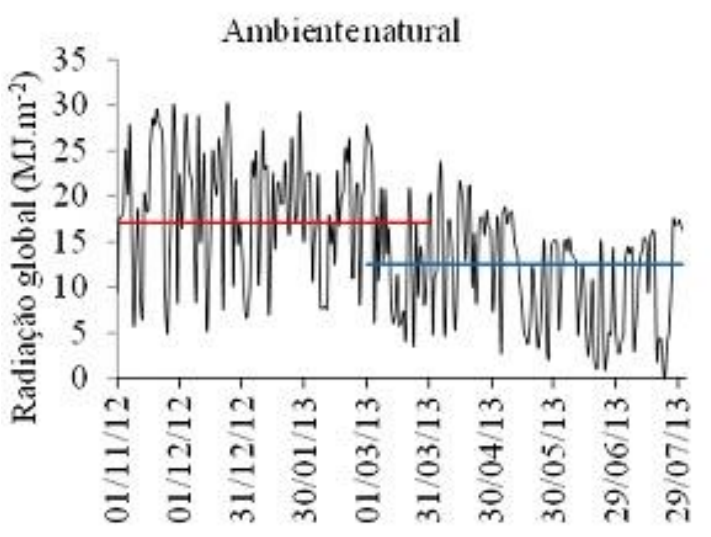

Periodo de condução do experimento

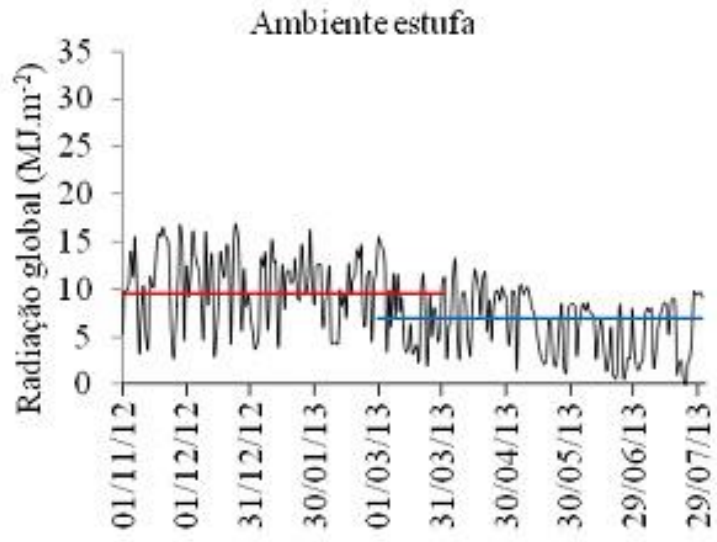

Periodo de conduçấo do experimento

$$
\text { - } \mathrm{Rg} \quad \text { Rg média verão }
$$

— Rg média outono

Figura 1. Incidência da radiação solar global no período de condução do experimento.

Figure 1. Incidence of global solar radiation in the period of conduct of the experiment.

About the net primary dry matter production, it was found that the treatments showed a positive linear relationship with RFAiac, with high coefficients of determination and with a response pattern dependent on seedling density, cultivation environment and seasons (Figure 2).
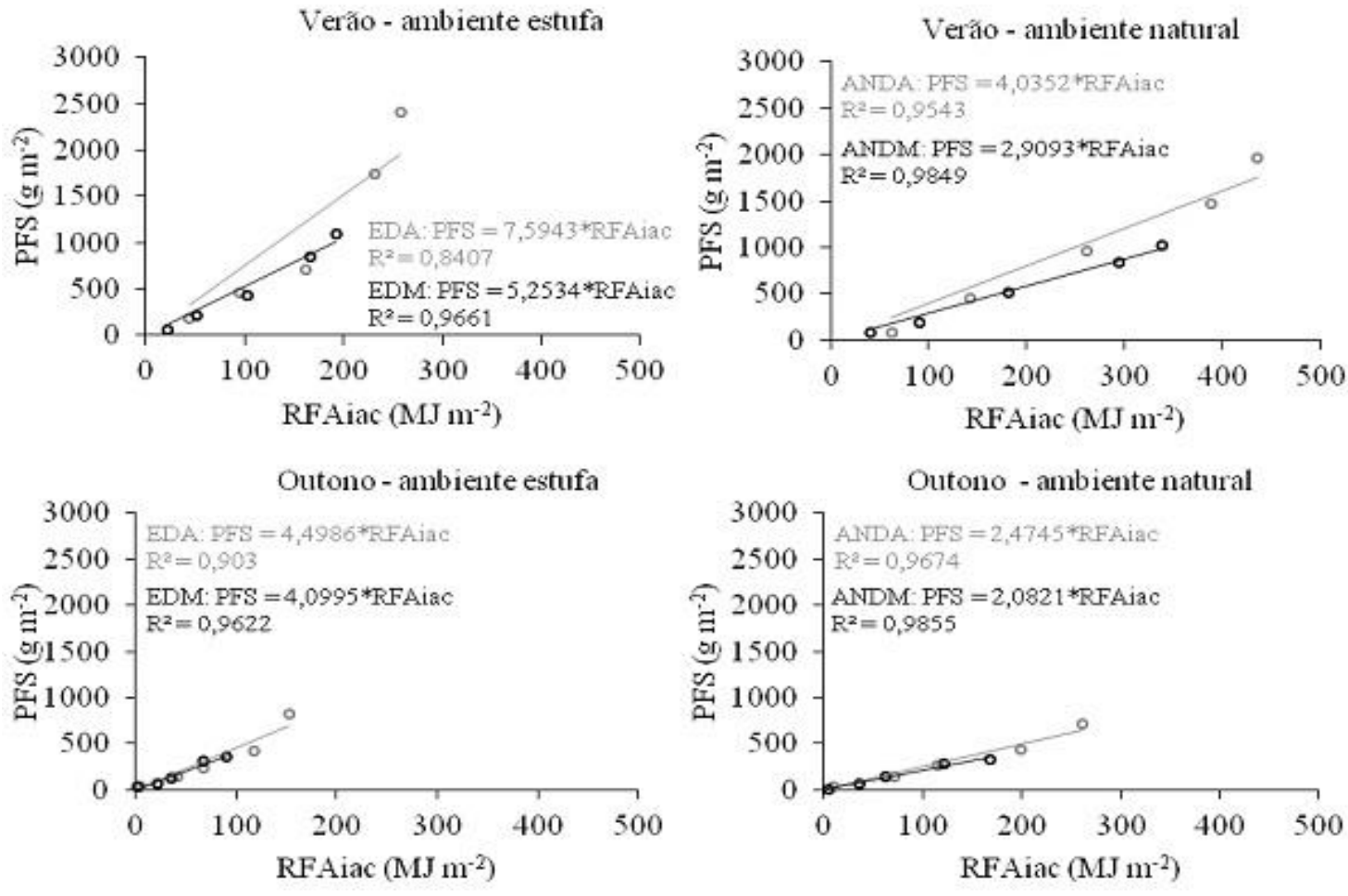

FLORESTA, Curitiba, PR, v. 50, n. 2, p. 1249 - 1258, abr/jun 2020 Costa Junior, S. et.al 
Where: HDG - high density greenhouse environment, MDG - medium density greenhouse environment, HDNE - high density natural environment, MDNE - medium density natural environment.

Figura 2. Produção primária líquida de fitomassa seca (PFS) de mudas de Eucalyptus dunnii em função da radiação fotossinteticamente ativa interceptada acumulada (RFAiac).

Figure 2. Net primary dry phytomass production (PFS) of Eucalyptus dunnii seedlings as a function of accumulated photosynthetically active intercepted radiation (RFAiac).

The variables IAF, RFAiac and DAE showed significant correlations between them. The highest Pearson correlation coefficients were found in treatments with high density in summer and medium density in autumn (Table 1).

Tabela 1. Correlação de Pearson entre IAF, RFAiac e DAE de mudas de Eucalyptus dunnii.

Table 1. Pearson correlation between IAF, RFAiac and DAE of seedlings of Eucalyptus dunnii.

\begin{tabular}{|c|c|c|c|c|c|c|}
\hline \multicolumn{7}{|c|}{ Summer } \\
\hline & IAF & RFAiac & DAE & IAF & RFAiac & DAE \\
\hline & \multicolumn{3}{|c|}{ greenhouse environment - high density } & \multicolumn{3}{|c|}{ greenhouse environment - medium density } \\
\hline LAI & 1 & $>0.001$ & $>0.001$ & 1 & $>0.001$ & $>0.001$ \\
\hline PARiac & 0,99 & 1 & $>0.001$ & 0,97 & 1 & $>0.001$ \\
\hline \multirow[t]{2}{*}{ DAE } & 0,97 & 0,99 & 1 & 0,95 & 0,98 & 1 \\
\hline & \multicolumn{3}{|c|}{ natural environment - high density } & \multicolumn{3}{|c|}{ natural environment - medium density } \\
\hline LAI & 1 & $>0.001$ & $>0.001$ & 1 & $>0.001$ & $>0.001$ \\
\hline PARiac & 0,97 & 1 & $>0.001$ & 0,96 & 1 & $>0.001$ \\
\hline DAE & 0,96 & 0,99 & 1 & 0,96 & 0,98 & 1 \\
\hline \multicolumn{7}{|c|}{ Autumn } \\
\hline & IAF & PARiac & DAE & IAF & PARiac & DAE \\
\hline & \multicolumn{3}{|c|}{ greenhouse environment - high density } & \multicolumn{3}{|c|}{ greenhouse environment - medium density } \\
\hline LAI & 1 & $>0.001$ & $>0.001$ & 1 & $>0.001$ & $>0.001$ \\
\hline PARiac & 0,98 & 1 & $>0.001$ & 0,99 & 1 & $>0.001$ \\
\hline \multirow[t]{2}{*}{ DAE } & 0,95 & 0,99 & 1 & 0,97 & 0,99 & 1 \\
\hline & \multicolumn{3}{|c|}{ natural environment - high density } & \multicolumn{3}{|c|}{ natural environment - medium density } \\
\hline LAI & 1 & $>0.001$ & $>0.001$ & 1 & $>0.001$ & $>0.001$ \\
\hline PARiac & 0,97 & 1 & $>0.001$ & 0,99 & 1 & $>0.001$ \\
\hline DAE & 0,94 & 0,99 & 1 & 0,98 & 0,98 & 1 \\
\hline
\end{tabular}

Key: IAF - Leaf Area Index, RFAiac - Accumulated intercepted photosynthetically active radiation, DAE - Days after the emergence of seedlings, the diagonal of $\alpha$ for $5 \%$ probability are shown.

The conversion efficiency $(\varepsilon b)$ of RFAiac in dry seedling phytomass in the summer and in the greenhouse was $7.59 \mathrm{~g} \mathrm{MJ}^{-1}$ in high density treatment and $5.25 \mathrm{~g} \mathrm{MJ}^{-1}$ under density average. Whereas in the natural environment, $\varepsilon b$ was $4.04 \mathrm{~g} \mathrm{MJ}^{-1}$ in the treatment under high density and $2.91 \mathrm{~g} \mathrm{MJ}^{-1}$ under medium density. In relation to autumn, values in the greenhouse environment were $4.50 \mathrm{~g} \mathrm{MJ}^{-1}$ in the treatment under high density and $4.10 \mathrm{~g} \mathrm{MJ}^{-1}$ under medium density, in the natural environment the $\varepsilon b$ was $2,48 \mathrm{~g} \mathrm{MJ}^{-1}$ in the treatment under high density and $2.09 \mathrm{~g} \mathrm{MJ}^{-}{ }^{1}$ under medium density (Figure 3).

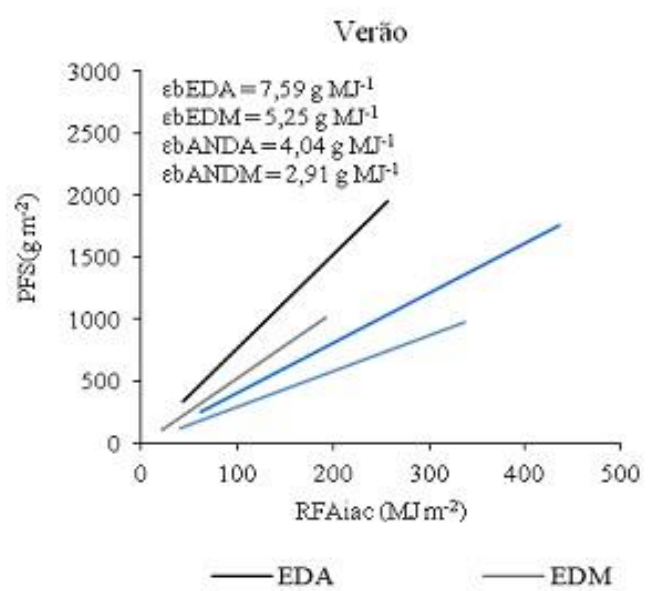

- EDA

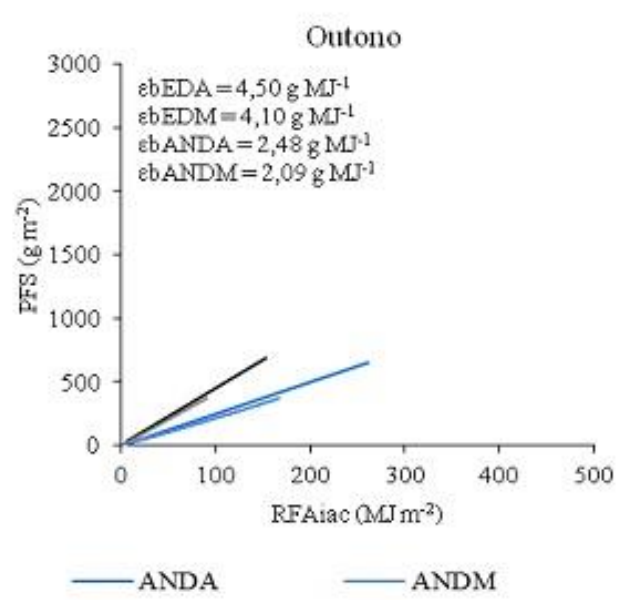

FLORESTA, Curitiba, PR, v. 50, n. 2, p. 1249 - 1258, abr/jun 2020 Costa Junior, S. et.al 
Key: EAD - high density greenhouse environment, EDM - medium density greenhouse environment, ANDA - high density natural environment, ANDM - medium density natural environment.

Figura 3. Eficiência de conversão da radiação fotossinteticamente ativa interceptada acumulada em fitomassa seca (cb) de plantas submetidas a duas densidades, dois ambientes de cultivo e a duas estações do ano.

Figure 3. Conversion efficiency of intercepted photosynthetically active radiation accumulated in dry phytomass (cb) of plants subjected to two densities, two cultivation environments and two seasons.

The analysis of covariance (ANACOVA) applied for independent regressions for all treatments within each season of the year (high density in the greenhouse environment $\mathrm{x}$ average density in the greenhouse environment $\mathrm{x}$ high density in the natural environment $\mathrm{x}$ average density in the natural environment) revealed a significant difference between the conversion efficiency values, indicating that the regressions have different slopes with their variation.

When verified the independent regressions for the different cultivation environments submitted to the same density, the analysis indicated the existence of a significant difference. The same result was obtained when comparing plant densities within the same environment, both in the summer and autumn seasons.

ANACOVA, when applied for independent regressions for all treatments contemplating the two seasons of the year (high density in the greenhouse environment in summer $\mathrm{x}$ high density in the greenhouse environment in autumn $\mathrm{x}$ high density in the greenhouse environment in summer $\mathrm{x}$ high density in the natural environment in autumn $x$ high density in the natural environment in summer $x$ high density in the natural environment in autumn), also revealed a significant difference between the efficiency values, indicating that the regressions present different inclinations with their variation.

When independent regressions for different seasons of the year with different growing environments submitted to the same density were verified, the analysis indicated a significant difference. The same result was obtained when comparing different seasons within the same environment with different plant densities, and also when comparing different seasons within the same environment with the same densities, thus indicating that the slopes varied with the season of the year, with the growing environment and plant density independently (Table 2).

Tabela 2. Análise de covariância entre as equações obtidas para descrever a produção de fitomassa seca por mudas de Eucalyptus dunnii em função da radiação fotossinteticamente ativa interceptada acumulada nos diferentes tratamentos.

Table 2. Analysis of covariance between the equations obtained to describe the dry phytomass production by Eucalyptus dunnii seedlings as a function of the intercepted photosynthetically active radiation accumulated in the different treatments.

\begin{tabular}{|c|c|c|c|c|c|}
\hline \multicolumn{6}{|c|}{ ANACOVA: summer } \\
\hline Variation Factor & GL & QM & $\mathrm{L}$ & $\alpha \mathrm{L}$ & EP \\
\hline $\begin{array}{l}\text { Difference for a single group } \\
\left(\mathrm{EDA}^{*} \mathrm{EDM}^{*} \mathrm{ANDA} * \text { ANDM) }\right.\end{array}$ & 3 & 327699,39 & 22,69 & $3.10 \mathrm{E}-05$ & No \\
\hline Difference - group EDA*EDM & 1 & 161778,03 & 7,42 & $3.10 \mathrm{E}-02$ & No \\
\hline Difference - group ANDA*ANDM & 1 & 93113,08 & 13,14 & $3.10 \mathrm{E}-02$ & No \\
\hline Difference - group EDA*ANDA & 1 & 634808,32 & 24,20 & $2.66 \mathrm{E}-03$ & No \\
\hline Difference - group EDM*ANDM & 1 & 139338,87 & 52,42 & $3.10 \mathrm{E}-04$ & No \\
\hline \multicolumn{6}{|c|}{ ANACOVA: autumn } \\
\hline $\begin{array}{l}\text { Difference for a single group } \\
\left(\mathrm{EDA}^{*} \mathrm{EDM}^{*} \mathrm{ANDA}{ }^{*} \mathrm{ANDM}\right)\end{array}$ & 3 & 3325355,22 & 14980,48 & $1.06 \mathrm{E}-21$ & No \\
\hline Difference - group EDA*EDM & 1 & 5302424,39 & 23999,31 & $4.88 \mathrm{E}-12$ & No \\
\hline Difference - group ANDA*ANDM & 1 & 4665990,02 & 20922,05 & $7,36 \mathrm{E}-12$ & No \\
\hline Difference - group EDA*ANDA & 1 & 7776823,64 & 20925,68 & $7,36 \mathrm{E}-12$ & No \\
\hline Difference - group EDM*ANDM & 1 & 2198120,11 & 30395,10 & $2,40 \mathrm{E}-12$ & No \\
\hline
\end{tabular}


ANACOVA: summer and autumn

\begin{tabular}{lccccc}
\hline $\begin{array}{l}\text { Difference for a single group } \\
\text { (VEDA*VEDM*VANDA*VANDM*OEDA*OEDM*OA }\end{array}$ & 3 & 5000474,64 & 681,93 & $2,37 \mathrm{E}-23$ & No \\
NDA*OANDM) & 1 & 3277403,94 & 167,34 & $1.31 \mathrm{E}-05$ & No \\
Difference - group VEDA*OEDM & 1 & 6128692,21 & 310,53 & $2.14 \mathrm{E}-06$ & No \\
Difference - group VEDA*OANDA & 1 & 1531463,96 & 669,39 & $2.20 \mathrm{E}-07$ & No \\
Difference - group VEDM*OANDM & 1 & 6750953,07 & 341,94 & $1.61 \mathrm{E}-06$ & No \\
Difference - group VEDA*OEDA & 1 & 1747453,45 & 766,754 & $1,47 \mathrm{E}-07$ & No \\
Difference - group VEDM*OEDM & 1 & 5102933,66 & 744,088 & $1,60 \mathrm{E}-07$ & No \\
Difference - group VANDA*OANDA & 1 & 1282052,02 & 2839,464 & $2.93 \mathrm{E}-09$ & No \\
Difference - group VANDM*OANDM & & & & &
\end{tabular}

Where: IP - Equal Parameters, EDA - greenhouse environment and high density arrangement, EDM - greenhouse environment and medium density arrangement, ANDA - natural environment and high density arrangement, ANDM - natural environment and medium density arrangement, VEDA - summer, greenhouse environment and high density arrangement, VEDM - summer, greenhouse environment and medium density arrangement, VANDA - summer, natural environment and high density arrangement, VANDM - summer, natural environment and medium density arrangement, OEDA - autumn, greenhouse environment and high density arrangement, OEDM - autumn, greenhouse environment and medium density arrangement, OANDA - autumn, natural environment and high density arrangement, OANDM - autumn, natural environment and medium density arrangement.

\section{DISCUSSIONS}

The lower availability of global solar radiation incident inside the greenhouse was due to transmissivity of the polyethylene (Figure 1). However, Cabrera et al. (2009) highlight that one properties of plastic cover is the diffusion of solar radiation, which is important because it is multidirectional and penetrates better into the vegetative canopy. Escobedo et al. (2013) found that polyethylene coverage increases the diffuse fraction of global solar radiation and that this is one of the main factors that favors the best development of a culture in a protected environment.

About the seasons, it was found that in the summer there was a greater increase in dry matter when compared to the autumn. This is due to the fact that the Rg's average has higher values in the first and last month of the year, decreasing in the months of June and July. The sky coverage also interferes with the radiation destined for photosynthesis, since in the region the sky remains cloudy for much of the time in the autumn period. This is in accordance with Escobedo et al. (2013), who verified the dependence between diffuse radiation inside a polyethylene greenhouse and the sky cover, so that diffuse radiation availability decreases as the sky changes from clear to cloudy. This situation directly interferes with plant growth and development.

Regarding the production of phytomass, by increasing the density of seedlings in the tray, the phytomass accumulated by the seedlings increased, what was also observed by Ataíde et al. (2010) and Caron et al. (2014). Another variable that also showed the highest values in high density crops regardless of the growing environment and the season was the IAF. Thus, the density of plants influenced the IAF, which directly affected the distribution of leaf area in the canopy of plants Consequently, the accumulation in dry matter obtained as a function of RFAiac in high density crops was the one that presented the highest values. This trend was also observed by Caron et al. (2012).

This demonstrates that plant arrangement is a management practice that should be considered, taking into consideration that the interaction with solar radiation interception is one of the main determinants of growth and development of a given crop.

When observing the angular coefficients obtained, it was found that they were dependent on the season, the cultivation environment and plant density, these factors being independent. When comparing the respective treatments for the seasons, it was found that the values of $\varepsilon b$ were higher in the summer. Comparing the environments, the values of $\varepsilon b$ in the greenhouse tended to be higher, while when comparing the cultivation densities, the high density tended to have higher $\varepsilon b$ values.

The conversion efficiency values of photosynthetically active radiation into phytomass obtained were close to those observed by Caron et al. (2014) in seedlings of Eucalyptus grandis Hill ex Maiden. grown in a greenhouse, with $7.33 \mathrm{~g} \mathrm{MJ}^{-1}$ in those submitted to high density, and $3.26 \mathrm{~g} \mathrm{MJ}^{-1}$ for medium density.

The treatments with the highest plant densities per tray were those that obtained the highest values for the leaf area index and, consequently, the highest conversion efficiency values. Thus, according to the increase in the leaf area index, there was a faster occupation by the leaf area of the spaces between the seedlings, which, 
consequently, increased the interception of the RFA. Proportionally, the production of phytomass was also higher, since this, as found, is a linear function of the accumulation of photosynthetically active radiation intercepted accumulated. Trautenmüller et al. (2017) also highlight that a higher IAF is related to greater biomass production, since the plant increases the interception of photosynthetic solar radiation.

In both cultivation environments, the conversion efficiency of cultivation under high density was approximately $28 \%$ and $11 \%$ higher when compared to those submitted to medium density, in the summer and autumn periods, respectively. Thus, the higher conversion efficiency obtained at high densities favored the greater accumulation of phytomass, reducing the time and space required to produce the same quantity of seedlings. The higher radiation use efficiency at high plant density per tray can also be explained by the increased relative contribution of the shaded leaves to the seedlings phytomass accumulation, which was also observed by Caron $e t$ al. (2012), who observed in the higher densities of eucalyptus seedlings an increase of $44 \%$ in conversion efficiency.

In this way, it can be inferred that cultivation under conditions of high plant density was more efficient, allowing greater interception of RFA in a shorter period of time. This situation occurs due to the faster occupation of the space between the seedlings by the leaf area during the growing period.

The seedlings grown in the greenhouse, regardless of the seasons and plant density, presented the highest conversion efficiency values of the RFAiac, approximately $46 \%$ more than when compared to those submitted to the natural environment. The higher values of radiation use efficiency in crops inside plastic greenhouses, when compared to those in natural environments, are explained by the increase of diffuse radiation in this environment. As demonstrated by Escobedo et al. (2013), the increase in diffuse radiation promotes greater uniformity of radiation inside the canopy, causing the lower leaves to increase the interception of radiation and also its use.

In both environments and crop densities, there was a difference of around $67 \%$ for the conversion efficiency values when compared to the seasons of the year in which the study was conducted. During the summer, all treatments resulted in higher conversion efficiency values for RFAiac, being associated with better meteorological conditions for these seasons, which directly influence plant growth and development.

In seedling cultivation, the supply of water and nutrients are limiting factors, but there is the possibility of controlling these elements. Thus, the production of phytomass is being controlled by solar radiation, which was observed and proposed by Monteith (1965). In this way, the growth of eucalyptus seedlings will depend on the amount of accumulated photosynthetically active intercepted radiation, the efficiency of use of this energy during the photosynthetic process, the density of plants per tray, the cultivation environment and the season.

The modeling of the efficiency by which the incident solar radiation is used in the accumulation of phytomass from eucalyptus seedlings is shown to be consistent in potential models and appropriate for the analysis of seedling growth, which has also been indicated by Müller and Bergamaschi (2005) for other crops.

The equations revealed that $\varepsilon b$ can explain more than $96 \%$ of the production of phytomass, with an estimated standard error of less than $26 \%$ for all cases. The modeling of the efficiency by which the incident solar radiation is used in the accumulation of phytomass from eucalyptus seedlings is shown to be consistent for potential and appropriate models for seedling growth analysis, which was also identified by Müller and Bergamaschi (2005) for other crops. This situation is also evidenced by the excellent statistics of fit the relations obtained between $\varepsilon b$ and the production of phytomass.

In this study, it was demonstrated that plant density, cultivation environment and season influence the growth of plants and their efficient use of RFA. It was also verified that the conversion efficiency values consist of an important input variable to be considered in growth models for seedlings, being useful to subsidize the planning of seedling production.

\section{CONCLUSIONS}

- The flow of global solar radiation is higher in the summer season, both in a natural environment and in a greenhouse environment, when compared to the same environments in the autumn season.

- The season, environment and density of plant cultivation independently influence the conversion efficiency values of photosynthetically active radiation into phytomass.

- Accumulated intercepted photosynthetically active radiation has a strong correlation with the days after emergence and leaf area index.

- For the same value of photosynthetically active radiation intercepted, the highest efficiency of radiation use is obtained in the accumulation of dry matter when Eucalyptus dunnii seedlings are grown in high density and in the greenhouse environment during the summer. 


\section{ACKNOWLEDGMENTS}

The Klabin company for the concession of seeds, INMET and SIMEPAR, for the granting of meteorological data.

\section{REFERENCES}

ATAÍDE, G.; CASTRO, R.; SANTANA, R.; DIAS, B.; CORREIA, A.; MENDES, A. Efeito da densidade na bandeja sobre o crescimento de mudas de eucalipto. Revista Trópica, Chapadinha, v. 4, n. 2, p. 21-26, 2010.

CABRERA, F.J.; BAILLE, A.; LÓPEZ, J.C.; GONZÁLEZ-REAL, M.M.; PÉREZ-PARRA, J. Effects of cover diffusive properties on the components of greenhouse solar radiation. Biosystems Engineering, Northumberland, v. 103, p. 344-356, 2009.

CAMPOE, O.C.; STAPE, J.L.; NOUVELLON, Y.; LACLAU, J.P.; BAUERLE, W.L.; BINKLEY, D.; MAIRE, G.L. Stem production, light absorption and light use efficiency between dominant and non-dominant trees of Eucalyptus grandis across a productivity gradient in Brazil. Forest Ecology and Management, Amsterdam, v. 288, p. 14-20, 2013.

CARON, B.O.; SCHMIDT, D.; MANFRON, P.A.; BEHLING, A.; ELOY, E.; BUSANELLO, C. Eficiência do uso da radiação solar por plantas Ilex paraguariensis A. ST. HIL. cultivadas sob sombreamento e a pleno sol. Ciência Florestal, Santa Maria, v. 24, n. 2, p. 257-265, 2014.

CARON, B.O.; SOUZA, V.Q.; TREVISAN, R.; BEHLING A.; SCHMIDT, D.; BAMBERG, R.; ELOY, E. Eficiência de conversão da radiação fotossinteticamente ativa interceptada em fitomassa de mudas de eucalipto. Revista Árvore, Viçosa, v. 36, n. 5, p. 833-842, 2012.

ESCOBEDO, J.F.; DAL PAI, E.; LENZ, L.C.; PRADO, M.B. Efeito da cobertura do céu no aumento das frações solar difusa e PAR-difusa em estufa de polietileno. Avances en Energías Renovables y Medio Ambiente, Salta, v. 17, n.2, p. 19-25, 2013.

GUIMARAES, C. C.; SCHUMACHER, M. V.; WITSHORECK, R.; SOUZA, H. P.; SANTO, J. C. Biomassa e nutrientes em povoamentos de Eucalyptus dunni Maiden no Pampa Gaúcho. Revista Árvore, Viçosa, v. 39, n. 5, p. $873-882,2015$.

Industria Brasileira de Árvores - IBÁ: Relatório Ibá 2017. 80p. Disponível em: <http://iba.org/images/shared/Biblioteca/IBA_RelatorioAnual2017.pdf> Acesso em: 30/01/2018.

MONTEITH, J.L. Climate and the efficiency of crop production en Britain. Proceedings of the Royal Society of London, London, v. 281, n. 980, p. 277-294, 1977.

MONTEITH, J.L. Light distribution and photosynthesis in field crops. Annals of Botany, Oxford, v. 29, p. 1737, 1965.

MÜLLER. A.G.; BERGAMASCHI, H. Eficiências de interceptação, absorção e uso da radiação fotossinteticamente ativa pelo milho (Zea mays L.), em diferentes disponibilidades hídricas e verificação do modelo energético de estimativa da massa seca acumulada. Revista Brasileira de Agrometeorologia, Santa Maria, v. 13, n. 1, p. 27-33, 2005.

SANQUETA, C.R.; BEHLING, A.; CORTE, A.P.D.; CADORI, G.C.; COSTA JUNIOR, S.; MACEDO, J.H.P. Eficiência de conversão da radiação fotossintética interceptada em fitomassa de mudas de Eucalyptus dunnii Maiden em função da densidade de plantas e do ambiente de cultivo. Scientia Forestalis, Piracicaba, v. 42, n. 104, p. 573-580, 2014. 
STAPE, J.L.; BINKLEY, D.; RYAN, M.G. Production and carbon allocation in a clonal Eucalyptus plantation with water and nutrient manipulations. Forest Ecology and Management, Amsterdam, v. 255, p. 920-930, 2008.

TAIZ, L.; ZEIGER, E. Fisiologia vegetal. Porto Alegre: Artmed, 2004. 618p.

TEIXEIRA, G. C. da S.; STONE, L. F.; HEINEMANN, A. B. Eficiência do uso da radiação solar e índices morfofisiológicos em cultivares de feijoeiro. Pesquisa Agropecuária Tropical, Goiânia, v. 45, n. 1, p. 9-17, 2015.

TRAUTENMÜLlER, J.W.; BORELlA, J.; MINATII, M. COSTA JUNIOR, S.; WOYCIKIEVICZ, A.P.F.; BALBINOT, R.; ENGEL, K. Crescimento de área foliar e índice de área foliar de mudas de Cordia americana em diferentes formas de manejo. Biofix Scientific Journal, Curitiba, v. 2, n. 2, p. 60-64, 2017.

VARLET-GRANCHER, C.; GOSSE, G.; CHARTIER, M.; SINOQUET, H.; BONHOME, R.; ALLIRAND, J. M. Mise au point: rayonnement solaire absorbé ou intercepté par um couvert végétal. Agronomie, Les Ulis Cedex, v. 9, n. 5 p. 419-439, 1989. 